\title{
The European character of Dubrovnik and the Dalmatian littoral at the end of the Enlightenment period: music and diplomatic ties of Luka and Miho Sorkočević, Julije Bajamonti and Ruđer Bošković*
}

\author{
Ivana Tomić Ferić
}

Taking a look into the life and artistic paths of prominent Croatian Enlightenment thinkers, musicians and diplomats in the context of their cities Dubrovnik (Luka and Miho Sorkočević, Ruđer Bošković) and Split (Julije Bajamonti), this paper intends to point to the broader context of their foreign activities and communication, whether direct or through extensive epistolary correspondence, with European intellectuals. For the purpose of presenting new thoughts and findings from recent musicological research, the text illuminates unknown data about Bajamonti's (musical) legacy, as well as about the relationship between composers from the Croatian coastal area in the late Settecento (the 1700s), clarifying their role in the penetration of European Enlightenment ideas to Croatian territory.

The reception of different foreign cultures, convergences, influences and permeations, and the reception and transformation of ideas testify to the intensive and continuous dialogue of cultural environments, circles and aspirations in this part of the Mediterranean. Generations of Croatian writers, philosophically and theologically educated scientists and artists were shaped in major European university centers, gaining academic titles, publishing their works and holding lectures at foreign universities and academies, engaging at the same time with central issues and ideals of their time and performing their tasks in the highest positions, both ecclesiastical and secular. All these characteristics are common to the abovementioned historical figures, who were part of cultivated Europe and were involved in the political and social changes that not only impinged on them but caught them in their whirlwind. Brothers Luka and Miho Sorkočević (and later Luka's son Antun, also a diplomat and musician) took part in these changes as high-ranking officials of the Dubrovnik Republic, while Julije Bajamonti, a learned polymath from Split, exerted a specific influence on the cultural and social life of

* This research has been fully supported by the Croatian Science Foundation under the project GIDAL IP-2016-06-2061. 
Croatian intellectuals, as well as on their presentation far outside Croatian lands, with his versatility and epistolary exchanges. ${ }^{1}$

Dubrovnik patrician, Count Luka Sorgo (Sorkočević in the Croatian version of the name; Dubrovnik, 1734-1789) was the ambassador of the Dubrovnik Republic to France in 1765, during the reign of Louis XV, and when Joseph II became the Emperor of Austria, the Republic sent him to the court in Vienna (in 1781). During his relatively brief stint in Vienna, he met several leading composers and poets of his time (Glück, Haydn, Metastasio), which was a valuable experience for his later life and work.

Like Sorgo, Ruđer Josip Bošković (Dubrovnik, 1711 - Milan, 1787), a famous naturalist and philosopher, also carried out very delicate diplomatic missions for the Dubrovnik Republic throughout his life. In the period between 1755 and 1776, he developed strong social contacts, and enjoyed a great reputation with the Holy See during his time in Paris (November 1759 - May 1760). He also had excellent relations with high-ranking French state authorities, especially with the Ministry of Foreign Affairs and the Versailles court, and was highly respected among French and English scholars (he became a fellow of the Royal Society in London in 1761). In the Austrian capital, he was recognized both for his diplomatic merits and as an outstanding scholar and author of the seminal work Philosophiae naturalis theoria redacta ad unicam legem viruim in natura existentium, published in Vienna in 1758. With his connections, he prepared Sorgo's trip to Vienna and arranged a welcoming atmosphere in his new diplomatic mission, as well as bringing him in contact with the famous Italian poet and most celebrated European librettist of the $18^{\text {th }}$ century, Pietro Metastasio (then residing in Vienna). ${ }^{2}$ Sorgo was a family

\footnotetext{
1 Most of Bajamonti's correspondence has been preserved in the Bajamonti Archive of the Archaeological Museum Split [Arheološki muzej u Splitu (AMS)]. It is a collection of letters and drafts in a number of volumes on a total of 227 A4-size pages, covering the period from April 16, 1787 to October 17, 1800 (a total of 1244 drafts), as well as fifty pages from August 9, 1771 to July 20, 1800. The alphabetical index of Bajamonti's drafts distinguishes 230 addressees-local and foreign scholars, writers, artists and public figures - with whom Bajamonti, occasionally or frequently, corresponded. Among others, we will mention the learned Hvar bishop Ivan Dominic Stratico, writers Ivan Luka Garanjin and Radoš Michieli-Vitturi from Trogir, French author Joseph de Lalande, Viennese librarian Michael Denis, astronomy professor at the Padua University Giuseppe (Josip) Toaldo, Leone (Lav) Urbani, a doctor from Split with a Venetian address, governor-generals of Dalmatia Paolo Emilio Canal and Angelo Diedo, Venetian printer and publisher Giacomo (Jakov) Storti, members of the Sorgo family, etc. See Ivana Tomić Ferić, "Susreti prekojadranskih kultura u razdoblju klasicizma: Bajamontijeve glazbene i izvanglazbene veze [Meetings of Trans-Adriatic Cultures in the Classical period: Bajamonti's Musical and Non-Musical Relations]," Bašćinski glasi 13 (2017/18): 73-121.

2 See Vjera Katalinić, "Korisne veze: Luka Sorkočević - Ruđer Bošković - Pietro Metastasio [Useful Liaisons: Luka Sorgo-Ruggiero Boscovich-Pietro Metastasio]," Arti musices 46/1 (2015): 27-35.
} 
friend of the Boškovićs, and he corresponded with Ruđer Bošković on various topics, particularly regarding the affairs of the Republic. ${ }^{3}$

As one of the most learned and most progressive figures, not only in Dalmatian but also in all of Croatian history, Julije (Giulio) Bajamonti (1744-1800), a native of Split (of Italian origin) - polymath, physician, writer, translator, linguist, bibliographer, historian, ethnographer, philosopher, economist, chemist, musician and musical theorist ${ }^{4}$ - developed strong and friendly relations with the Sorgo brothers. He probably met Luka Sorgo through his younger brother Miho (Dubrovnik, 1739 - Paris, 1796), and the preserved correspondence confirms their mutual respect and commitment to enrich the cultural life of their cities. From the transcripts of Bajamonti's drafts of letters addressed to Luka (kept today in the Bajamonti Archive of the AMS, sign. XII/A, Koncepti korespondencije)5, we can learn a great deal about the origin and the performance of the Bajamonti's Mass for the Dead (Messa da morto) in F major for male choir, soloists and orchestra, composed in May 1787, on the occasion of preparations for the solemn memorial service given by the Senate of the Dubrovnik Republic in the Cathedral in honor of Ruđer Bošković. The score reflects Bajamonti’s evident enthusiasm for Boškovićs work, which marks a distinct period in the history of natural sciences.

\footnotetext{
3 The Kaznačić legacy in the Archives of the Croatian Academy keeps some of Bošković's letters, among others those addressed to Luka Sorgo. See Archives of the Croatian Academy, Fond Kaznačić, XV 2/I-85, Bošković's letters to Luka Sorgo, 1780, Zagreb.

4 Bajamonti was engaged in music in many ways, not only as a composer, music teacher and Kapellmeister at the Split Cathedral (1790-1800), but also as a reproducer, folk music transcriber and musical theorist and author of the first encyclopedically conceived dictionary of music compiled in Croatia, with three hundred entries from the field of musical theory and organology. See Ivana Tomić Ferić, Julije Bajamonti (1744.-1800.): Glazbeni rječnik [Julije Bajamonti (1744-1800): Dictionary of Music] (Zagreb: HMD, 2013).

5 The correspondence kept in the AMS is divided into two groups: group A (Julije Bajamonti's Archive in AMS, sign. XII/A, Correspondence Drafts) contains the drafts of letters Bajamonti sent to others, while group B (Julije Bajamonti's Archive in AMS, sign. XII/B) includes letters sent to Bajamonti by others. Correspondence from group B is partially arranged and classified and carries the signature XII/B with an additional number of the folder in which the letters are stored from individual subgroups (for example, the correspondence between Miho Sorkočević and Bajamonti has the signatures XII/B-111-1 and XII/B-111-2). There is, however, a considerable problem with the part of the archive that Bajamonti used for his debates and as notes, so the letters of some people to Bajamonti remain unarranged and scattered across different parts of the archive. In order to complete the list of preserved letters, it is necessary to mark the pages of the entire material and compare it with data from existing studies. This way we will be able to reveal which letters actually exist and whether there are any deviations in relation to the existing cataloguing of the archives. This is one of the goals of the announced project GIDAL IP-2016-06-2061 (acronym for the four-year scientific musicological project Musical Sources of Dalmatia in the Context of Central European and Mediterranean Music Culture from the $18^{\text {th }}$ to the $20^{\text {th }}$ Century), led by the author of this text. For the purpose of this study, we used archival material from group XII/A (Bajamonti's drafts) and from XII/B-111 (Correspondence Miho Sorkočević-Julije Bajamonti).
} 
After the death of the great scholar in 1787, Luka Sorkočević (responsible for the musical aspect of the memorial service) approached Bajamonti (then serving on the island of Hvar) and asked him to send a commemorative requiem from his own musical archive. The Dubrovnik composer sought a vocal mass for the dead with instrumental accompaniment that he would be able to prepare in time for the performance at the Dubrovnik Cathedral. From his request and Bajamonti's response, it is possible to observe the state of church music in Dalmatian cities in that time, especially in Dubrovnik and Split. Bajamonti, in fact, did not have any appropriate requiem in his collection, and only managed to find two masses for the deceased "in the Franciscan style, without instrumental accompaniment," probably simple masses for two voices rhythmized in the manner of cantus fractus, which in his opinion did not fit the intended purpose. However, he knew Pellizzari's requiems and considered them appropriate, but they also lacked instrumental accompaniment. ${ }^{6}$ For this reason, he decided to compose a requiem himself, grateful that he had been given the opportunity, in the absence of other masses, to present his work in honor of the "immortal" Bošković. Wanting to win the favor of the Dubrovnik nobility through Luka's support, he completed the requiem in a short time: in the first letter of May 11, 1787, he says that he had started composing, and less than two weeks later, in a letter of May 23, he proudly states that he is waiting for the occasion and favorable weather conditions to send the completed composition in time (see Appendix 1 and 2). Assuming that the musicians in Dubrovnik would be engaged in the premiere performance of his piece, Bajamonti, along with the score, sent instructions to the performers, accompanied by a commemorative sonnet, which he wrote in Ruđer Boškovićs honor. Performance instructions can be viewed as a kind of preface to the work: Bajamonti decided to compose a mass for two tenor voices and one bass, which was a common ensemble of church singers, and along with string instruments intended to introduce wind instruments (since there were some in Dubrovnik), but if necessary, the composition could also be performed with strings only, with two violins or the organ taking the wind parts. ${ }^{7}$

\footnotetext{
6 Bajamonti's musical activity started very early in his youth when he began to acquire basic knowledge in musical theory and musical skills in his native Split by studying with the then Kapellmeister of the Split Cathedral Benedetto Pellizzari (?-1789), an Italian from Vicenza. Pellizzari was doubtlessly the most popular and most fruitful composer on the eastern shores of the Adriatic in mid- $18^{\text {th }}$ century. About 400 of his compositions are spread throughout music collections from Koper (Capodistria) to Kotor (Cattaro), but are largely kept in Split, where he was active from 1753 and was mainly attached to the church with teaching obligations. See Ivana Tomić Ferić, "Cultural contacts between the two shores of the Adriatic in the second half of the eighteenth century, as exemplified in the works and correspondence of Julije Bajamonti," in L'Adriatico tra sogno e realta, edited by Persida Lazarević Di Giacomo and Maria Rita Leto (Alessandria: Edizioni dell'Orso, 2019), 229-269.

7 In his letters, Bajamonti does not list the entire ensemble, but only mentions violins and the organ, strings and winds. The string ensemble is evident from the score, and when listing wind
} 
He intended to compose the choral parts for moderate vocal range and performance requirements, as he did not know the vocal competences of the singers. Therefore, his instructions explain that, in the absence of soloists for each part, singers of the nearest vocal range can perform instead, i.e. the bass or the first tenor can sing most of the solo sections of the second tenor and vice versa.

Unfortunately, the original score of Requiem was not preserved in full in the Musical Archive of the Split Cathedral (GASK, international archival signature HRSk): today, we can find only the incomplete score, parts and a transcript of Sanctus and Agnus Dei (identified by Vito Balić during the most recent examination of the GASK). ${ }^{8}$ There is no composition title on the cover page of the score and on the parts that are in Bajamonti's handwriting. There is only a dedication on the cover page: "Per le solenni esequie / decretate dal Senato di Ragusa / a suffragio dell'anima dell'immortale / ab. Boscovich [For the solemn memorial service / ordered by the Senate of Dubrovnik / for the rest of the immortal soul / of abbot Bošković]."

From the musical perspective, the score confirms Bajamonti's interest in local folk music, and with its simple homophonic structure is a counterpoint to pieces he had written to Metastasio's verses, which show influences of contemporary trends of Italian opera. The musical form follows the form and content of the mass text, and the musical figures reveal a good connoisseur of Pellizzari's music and a

instruments (oboe, flute, horn, trumpet), the composer considers the performance possibilities in Dubrovnik. From the first page of the score, we can clearly see the instrumental ensemble: first and second violin, viola and string bass, as well as two oboes, which may be replaced by two flutes and two horns accompanied by an organ that contains only a figured bass part (see Appendix 2, A copy of Bajamonti's draft).

8 The incomplete score (HR-Sk-V/55:1, $30.4 \times 22.6 \mathrm{~cm}$ ) is written on a sheet of 10 -stave music paper and consists of unbound bifolia (8 pages). Only the first two bifolia (16 pages), up to the $43 \mathrm{rd}$ bar of Kyrie, have been preserved. The first page of the score bears the remark "Incontrata, $e$ trovata completa" by an unidentified archivist, according to which it is clear that the GASK had the full score of the Requiem until an unidentified point in time. The movements Sanctus and Agnus Dei ("miscelanea", HR-Sk-XCIX/1674:201c) are added to the collection in three three-part sections in the form of a choral score along with a thorough bass part. There are 16 preserved parts (HR-Sk-V/55:2-17; only the viola part is missing), and they are written on the same type of paper in three different manuscripts. The score, including bass, horn and string bass, are in Bajamonti's handwriting, but without the name of the composition or instrument and without the signature. Two tenor and two violin parts were written in a handwriting resembling Bajamonti's with the handwritten title of the composition and the author's name ("Messa da morto a 3 voci con stromenti" or "Messa de' morti a tre voci con stromenti" / "Del Nob. Sig: D:r Giulio Bajamonti") and the full name of the part, but without mentioning Bošković. The handwriting of two other violin parts (HR-Sk-V/55:13,15) are slightly different. The handwriting in the remaining parts is noticeably different. While one possible explanation is that someone helped Bajamonti write these parts, it is also possible that the Requiem was performed on different occasions, for which other Kapellmeisters also copied the parts. For the transcribed movements Sanctus and Agnus Dei from the Requiem, there is no doubt that they were repeatedly performed. See Ivana Tomić Ferić, Vito Balić (Eds.), Requiem for Ruđer Bošković (Sheet Music: Musical sources of Dalmatia, Vol. 3) (Split: Arts Academy, University of Split, 2019). 
specialist in composing church music. Having completed the mass and the sonnet, Bajamonti asked Count Lukša, as he intimately used to call the older brother Sorgo, to send him all the commemorative speeches that would be published in Dubrovnik on the occasion of Bošković's death (see Appendix 3). However, despite sending the score and the sonnet to Dubrovnik via Sergeant Resićs felucca on June 1, 1787 (as reported by Luka Sorkočević in a letter dated June 2 of the same year) ${ }^{9}$, Bajamonti's composition did not arrive in time to be performed at the solemn memorial service, as his letter of July 19 reads (see Appendix 4). Nonetheless, it was performed a little later (June 25), at a private concert, probably at the palace of the Sorkočević family in Komolac, in Rijeka Dubrovačka. After composing the Requiem, Bajamonti began writing his Eulogy for Ruđer Bošković, which he completed only in 1789 and published it with the support of Miho Sorkočević, first in Dubrovnik (Elogio del Boscovich) ${ }^{10}$ and then a year later in Naples (Elogio dellabate Ruggiero Giuseppe Boscovich). ${ }^{11}$

Wanting to be different from others, Bajamonti studied in detail all the eulogies written in Boškovićs honor that he received from his Dubrovnik friends, and wrote a lot about his own eulogy in the letter drafts (he gave the most complete review to Miho Sorgo in a letter dated August 2, 1789). ${ }^{12}$

As one of the most prominent citizens of Dubrovnik, who performed important duties in the service of the Republic and was a member of the Roman Academy of Arcadia, Miho Sorgo had a cordial friendship with many European intellectuals, especially with Paduan naturalist and travel writer Alberto Fortis (Padua, 1741 - Bologna, 1803), the author of the popular travelogue Viaggio in Dalmazia (Venice, 1774). Fortis became famous in Europe for showing the world the previously unknown treasure of the eastern Adriatic coast, and he maintained contact not only with Sorgo but also with other Dalmatian writers and philosophers. With Bajamonti he discussed many topics and details-biographical, scientific, political, social, economic and cultural-constantly presenting and exchanging their own and others' discussions and books. Their correspondence shows the penetration and permeation of Enlightenment ideas on the Adriatic coasts in mid- $18^{\text {th }}$ century, reflecting the universality of the spirit and the lifestyles of its authors. In collaboration with Miho Sorgo, they shared in their letters thoughts

\footnotetext{
9 "A 2 Giugno 87. Al C(onte) Sorgo ò dato avviso d'averli spedita la messa da morto colla filucca del serg(en)te Resich partito ieri [...]”, AMS, XII/A, p. 15 (Letter from June 2, 1787).

10 The Institute for Historical Sciences in Dubrovnik - Croatian Academy of Sciences and Arts, Mescolanze raccolte da Giovanni de Bizzarro, Vol. I, t. 6. Elogio del Boscovich. Ragusa: Andrea Trevisan, 1789, Dubrovnik.

${ }^{11}$ Elogio dell'abate Ruggiero Giuseppe Boscovich (Napoli: Presso Donato Campo, 1790), VIII+40 p., kept in the National and University Library in Zagreb, R II F-40-167; Biblioteca nazionale Vittorio Emanuele III - Napoli, Sala 6a Misc. A.25/12.

12 See the full transcript in Appendix 5.
} 


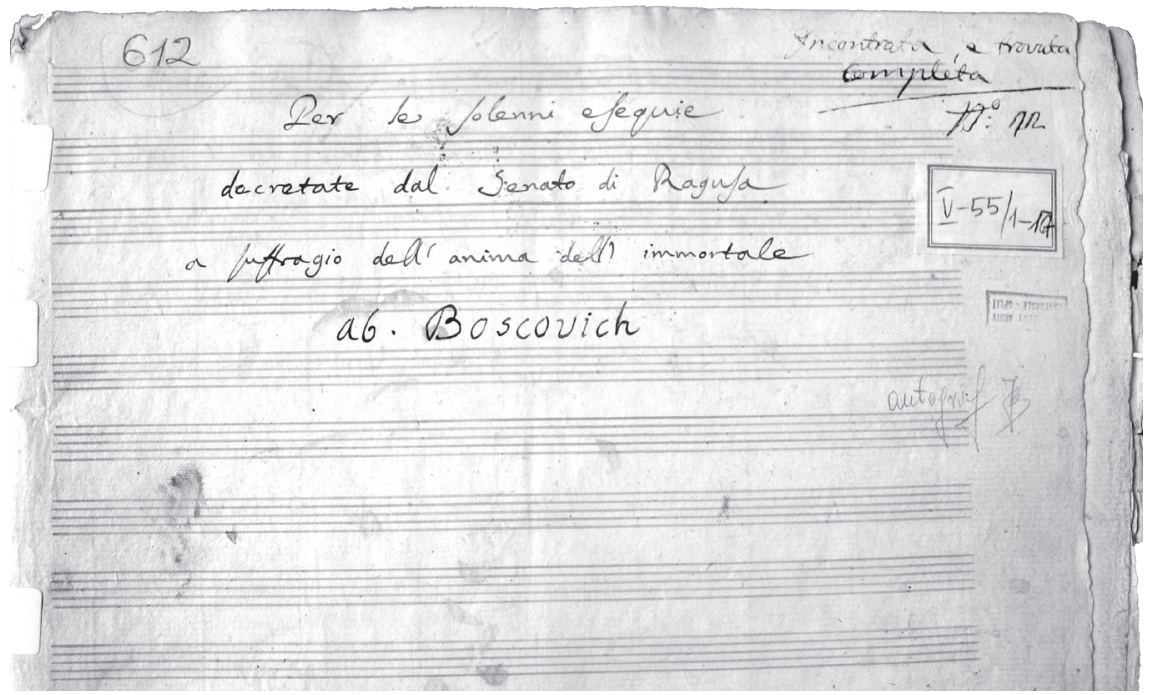

Figure 1. Bajamonti's dedication to Bošković, autograph, the first page of the incomplete Requiem score. HR-Sk-V/55:1.

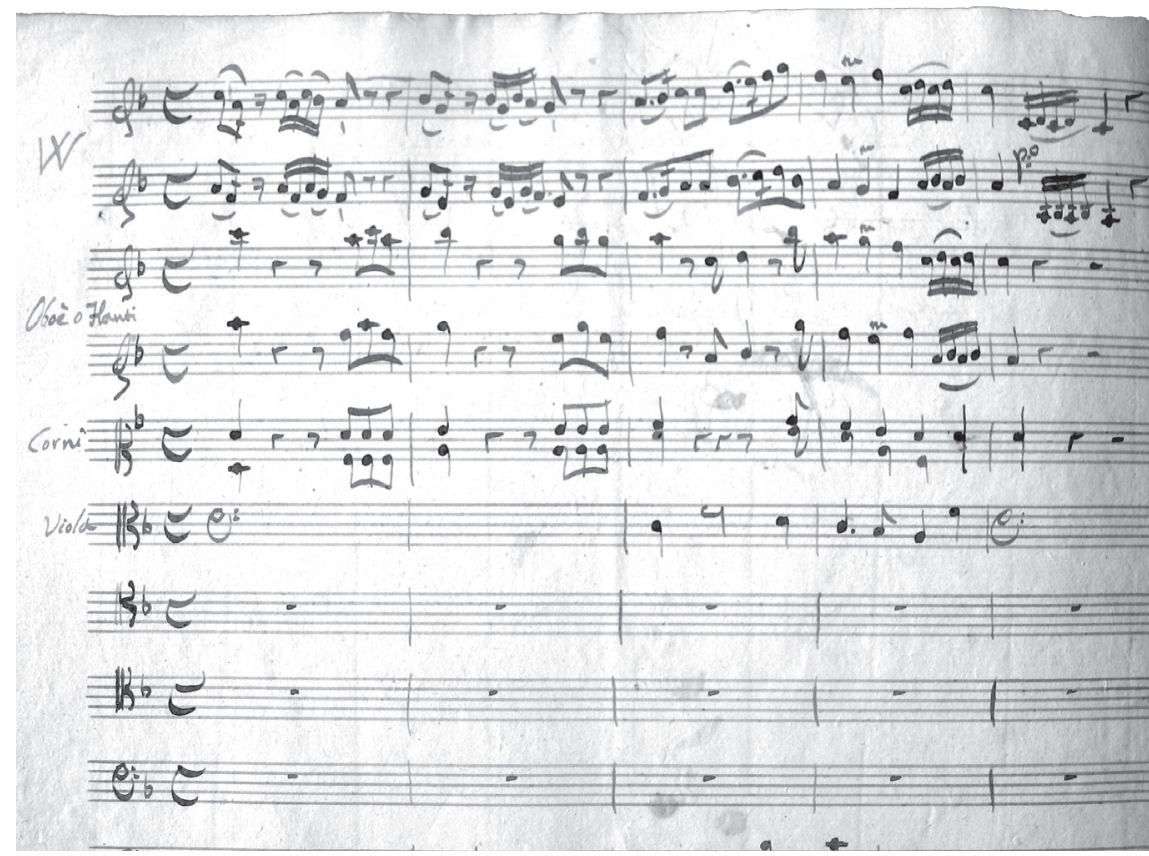

Figure 2. The beginning of Bajamonti's Requiem, autograph, the second page of the incomplete score. HR-Sk-V/55:1. 
about literature, poetry, music, friends and news from Dubrovnik, Split or Hvar. All of them respected and honored each other, continually sharing, reviewing or commenting on their own and others' studies and ideas (see Appendix 6, a copy of Miho Sorkočevićs letter to Bajamonti). In honor of Fortis, Miho Sorgo prepared and published in 1790 a poetic composition Albertus Fortius Rhacusa discendens, with Bajamonti's Italian translation.

The writing style of this Croatian follower of the Enlightenment is modern and close to the level of European classicist thoughts, as is evident from his distancing from scholastic philosophy and its later branches, from the pathos similar to baroque tradition and oriented toward practical reflection in which philosophy is linked to politics in order to create a rich, modern nation. In the field of music, the compositions of Bajamonti and Luka Sorgo fit into a compositional-technique framework of the period of breaking from the old, Baroque style into a new, Classical one, and were an integral part of the creative practice of the time. Bajamonti's musical legacy is quite extensive and includes about 230 sets or fragments of various pieces, where secular forms are less represented (arias, duets, choir songs and chants, symphonies), while most of the opus contains church music (motets accompanied by the organ or chamber orchestra, masses, passions, requiems, responsorial psalms, anthems, Te Deums). The oratorio La Traslazione di San Doimo from 1770 is the first Croatian oratorio but also one of the most significant pieces of Croatian $18^{\text {th }}$-century music, which synthesizes Bajamonti's historical research, his literary work, composing and performing inspirations. In his youthful compositions (mostly sacred), he was under a strong influence of Pellizzari, who built his opus on a rather unproblematic link between the characteristics of the Baroque and the pre-Classical style. ${ }^{13}$ Bajamonti was much more progressive, but he made a complete departure from Pellizzari only after he was acquainted with the musical life and culture in more developed centers of music of Padua and Venice in the course of his studies. In Italy, he had the opportunity to meet, hear, analyze and transcribe valuable achievements of Italian and other composers, especially German ones (e.g. Paisiello, Stamitz, Mozart, Glück), who essentially determined his own creative expression. He brought numerous scores from Italy, both his own and transcripts or adaptations of other works, which prove that he was relatively up to date and fairly open to formal innovations that fluctuated on the western coast of the Adriatic. ${ }^{14}$ By emphasizing the Italian influence and the use of Pietro Metastasio's verses in Bajamonti's compositions, Belamarić dares to claim that Bajamonti's work will have its real frame only in a formal style

\footnotetext{
${ }^{13}$ Miljenko Grgić, "Dr. Julije Bajamonti, glazbenik [Dr. Julije Bajamonti, the musician]," in Split's polymath Julije Bajamonti, edited by Ivo Frangeš (Split: Književni krug, 1996), 87-117.

${ }^{14}$ For more details about the pieces from Padua and Venice handwritten by Bajamonti (unsigned) presenting the musical characteristics and phraseology of Italian music authorities, whose work the polymath from Split studied, see Grgić, “Dr. Julije Bajamonti,” 90.
} 
confrontation with related works of a relatively broad Italian composing front of his age. ${ }^{15}$ Moreover, he believes that instead of listing his authenticated pieces, it would be much more useful to study the share of Bajamonti's interventions and digressions from patterns in adaptations of the works of Guglielmi, Anfossi, Sacchini, da Capua and other Italian masters. ${ }^{16}$ Only through a comparative study would it be possible to evaluate the influence of his immediate environment-more noticeable in his late creative period when, inspired by the pre-Classical style and compositions of Luka Sorgo, Bajamonti turns to folklore and elements of simple folk dances-against inarguable Italian formal and stylistic references that he might have taken or copied in his compositions, be it intentionally or unintentionally.

Luka Sorgo's symphonies are also marked by the spirit of early Classicism, in fact they are the first and most authentic testimonies of Croatian pre-Classical musical thought-but there are some differences in comparison with the composing style of his younger colleague. While Bajamonti was powerfully influenced by Venetian opera, just as Split and Dalmatia were oriented to Venice as their main focus in culture, Luka, as a representative of the Dubrovnik Republic, which communicated with various centers and milieus, was more oriented to wider musical and cultural currents, the kind that could be felt in Rome, Milan, Vienna and in particular the innovations that Glück and his Viennese and Parisian works had introduced. ${ }^{17}$ We can learn about Sorgo's personal contacts with Glück, as well as Metastasio, Haydn and other leading composers and artist of the time, from the diary that he wrote during his journey to Vienna and his return to Dubrovnik. Thanks to this document, we can follow his experiences in Vienna, where he described, above all, a series of encounters and events related to politics and diplomacy, but also some related to culture and music, as well as other social events. ${ }^{18}$ It was precisely this connection he maintained with prominent individuals, scholars and artists that essentially contributed to his Enlightenment tendencies.

Like his older brother, Miho Sorgo also developed through different diplomatic tasks for the Dubrovnik Republic a dense network of contacts with writers interested in the history and customs of Slavs-from Italian authors Melchiore Cesarotti and Alberto Fortis to Spanish theater and music writer Esteban de Arteaga - as well as Bošković, whose oeuvre forms a separate and respectable

\footnotetext{
15 Joško Belamarić, "Metastasijevi stihovi u skladbama iz Glazbenog arhiva splitske katedrale [Metastasio's verses in compositions kept in the Musical Archive of the Split Cathedral]," Arti musices 11 (1980): 157-201.

16 Ibid., 167.

17 Vjera Katalinić, Sorkočevići dubrovački plemići i glazbenici [The Sorkočevićs, the Nobles and Musicians from Dubrovnik] (Zagreb: Muzički informativni centar Koncertne direkcije Zagreb, 2014), 151-153.

18 The diary is kept in the Dubrovnik State Archive. For more details about its content, see Katalinić, Sorkočevići, 48-71.
} 
part in the whole history of natural sciences among Croats. It is interesting to note that, besides written communication, Luka Sorgo and Ruđer Bošković had the opportunity to meet Pietro Metastasio in person, with many mutual compliments and praise. Presenting one of Metastasio's letters to Bošković, sent from Vienna to Paris on August 18,1781, Katalinić highlights a section where the Italian poet praises Luka Sorgo's refinement and erudition, his manners, and noble and rational behavior with which he won over the Viennese nobility. ${ }^{19}$ It can be assumed that Count Lukša shared his positive impressions about the "sincere, natural and clever" 20 Metastasio with his colleague from Split, especially taking into consideration the series of scores Bajamonti composed to his verses, which are stored in the Musical Archive of the Split Cathedral. In the case of all the historical figures presented here, we can conclude that they constantly broadened the narrow frames of understanding life and the world around them. With their creative and social activities, open-mindedness and sensitivity to cultural and spiritual values, they strongly represented the general spirit of the Enlightenment. It seems that those thirsting for scientific and cultural progress made their cities open to foreign artist, musicians, theatre ensembles, scholars, naturalists and travelers, who enriched the cultural life of the Dalmatian littoral at the end of the Enlightenment period.

By establishing connections and contacts with foreign individuals, circles and institutions, and fostering sensitivity to their own cultural and spiritual values, Julije Bajamonti, brothers Luka and Miho Sorgo and Ruđer Bošković combined in their work and activities all the important features of 18th-century local and European culture. With their refined views and beliefs, their eminent knowledge and artistic dedication, they devoted themselves and their work to the mission of the Enlightenment and remain to this day a model of noble and self-sacrificing modesty, but also of lasting value in shaping Croatia's cultural identity and its international confirmation.

The relations of Croats with other Western European countries in the $18^{\text {th }}$ century were prolific and diverse, and their revelation evokes the undeniable values of national achievements in various branches of science and art. They testify to the greatness of "small peoples," to the development of cultural identity as a result of the intertwining of different traditions, civilizational circles, opinions and influences. In the sphere of musical history, it is difficult to estimate how strong the centripetal force was with which prominent European centers (e.g. Venice, Padua, Rome, Naples, Vienna) tinged musical activity in Dalmatia, but it is more than certain that the encounters, permeation and transformation of cultural traditions happened directly-by direct transmission of tradition and influence-from teachers to students and indirectly through the exchange of instruments, scores, repertoire and music

\footnotetext{
19 Ibid., 27-35.
}

${ }^{20}$ Ibid., 29. 
books. That is why the research presented here, analyzing the concrete examples of intercultural interactions through selected parts of Bajamonti's, Sorkočevićs and Bošković's legacy in the wider musicological, cultural and political context has current relevance.

By building a recognizable distinctiveness, Croats, as "the antemurale of Europe," contributed to its spiritual communion. Examples of this togetherness and cultural synthesis are found in Croatian Petrarchism, Latinism, Dantology, but also in the ideas of the Enlightenment followed and developed by all these great individuals whose activities we discussed. 


\section{Primary sources:}

Archeological Museum in Split (AMS): Archives of Bajamonti's legacy, XII/A: 1-228, Correspondence Drafts, 1787-1789, Split.

Archeological Museum in Split (AMS): Archives of Bajamonti's legacy, XII/B-111-3, Correspondence Miho Sorkočević - Julije Bajamonti, 1779, Split.

Musical Archive of the Split Cathedral (GASK): HR-Sk-V/55:1, Julije Bajamonti, Requiem for Ruđer Bošković, 1787, Split.

Archives of the Croatian Academy of Sciences and Arts: Fond Kaznačić, XV 2/I-85, Boškovićs letters to Luka Sorgo, 1780, Zagreb.
The Institute for Historical Sciences in Dubrovnik - Croatian Academy of Sciences and Arts, Mescolanze raccolte da Giovanni de Bizzarro, Vol. I, t. 6. Elogio del Boscovich, Ragusa: Andrea Trevisan, 1789, Dubrovnik.

National and University Library in Zagreb, R II F-40-167, Elogio dell'abate Ruggiero Giuseppe Boscovich, Napoli: Presso Donato Campo, 1790, Naples.

Biblioteca nazionale Vittorio Emanuele III Napoli, Sala 6a Misc. A.25/12, Elogio dellabate Ruggiero Giuseppe Boscovich, Napoli: Presso Donato Campo, 1790, Naples.

\section{References:}

Belamarić, Joško. "Metastasijevi stihovi u skladbama iz Glazbenog arhiva splitske katedrale." Arti musices 11 (1980): 157-201.

Duplančić, Arsen. "Ostavština Julija Bajamontija u Arheološkom muzeju u Splitu i prilozi za njegov životopis." In Split's polymath Julije Bajamonti, edited by Ivo Frangeš, 13-80. Split: Književni krug, 1996.

Grgić, Miljenko. "Dr. Julije Bajamonti, glazbenik." In Split's polymath Julije Bajamonti, edited by Ivo Frangeš, 87-117. Split: Književni krug, 1996.

Katalinić, Vjera. "Korisne veze: Luka Sorkočević-Ruđer Bošković-Pietro Metastasio." Arti musices 46/1 (2015): 27-35.

Katalinić, Vjera. Sorkočevići dubrovački plemići i glazbenici. Zagreb: Muzički informativni centar Koncertne direkcije Zagreb, 2014.

Stojan, Slavica. "Kulturni krug Luke i Miha Sorga (Sorkočevića): Glazbenici, pjesnici i diplomati." Anali Dubrovnik 54/2 (2016): 247-262.

Tomić Ferić, Ivana. "Cultural contacts between the two shores of the Adriatic in the second half of the eighteenth century, as exemplified in the works and correspondence of Julije Bajamonti." In L'Adriatico tra sogno e realta, edited by Persida Lazarević Di Giacomo and Maria Rita Leto, 229-269. Alessandria: Edizioni dell'Orso, 2019.

Tomić Ferić, Ivana. Julije Bajamonti (1744.1800.): Glazbeni rječnik. Zagreb: HMD, 2013.

Tomić Ferić, Ivana. "Suradnja s Julijem Bajamontijem." In Luka \& Antun Sorkočević, diplomats and composers, edited by Pavica Vilać, 233-263. Dubrovnik: Dubrovnik Museums, 2014.

Tomić Ferić, Ivana. "Susreti prekojadranskih kultura u razdoblju klasicizma: Bajamontijeve glazbene i izvanglazbene veze." Bašćinski glasi 13 (2017/18): 73-121.

Tomić Ferić, Ivana, Balić, Vito (Eds.). Requiem for Ruđer Bošković. Sheet Music: Musical sources of Dalmatia, Vol. 3. Split: Arts Academy, University of Split, 2019.

Wolf, Larry. Venice and the Slavs. The Discovery of Dalmatia in the Age of Enlightenment. Stanford: Stanford University Press, 2001. 


\title{
APPENDICES \\ (Transcripts of Bajamonti's letters/drafts)
}

\author{
Appendix 1 \\ Bajamonti's letter to Luka Sorgo, \\ May 11, 1787, XII/A, AMS, p. 3-4
}

Al s(igno)r Conte Luca Sorgo. A Ragusa.

Da Lesina 11 Maggio 87.

La sua lettera dei 24 Aprile pross(imo) pass(ato) më pervenuta solam(en)te due giorni fa col mezzo di un venditore di bagatelle, il quali dice di averla ricevuta costà dal sig(no)r Angiolino sonatore. Non avendo io messe da morto fra le mie carte di musica, ho usato ogni diligenza per trovarne qui presso qualcheduno altro, ma non ne ho trovato che due, di gusto zoccolante, senza strumenti, e da non cantarsi a unianima matematica. Quelle del maestro di capella di Spalatro, che per'altro sarebbone ben opportune mancano pur dell'accompagnamento istrumentale; perché essendo colà determinato il prezzo de' mortorj in musica, il quoziente de' preti cantori patirebbe qualche sottrazione alorché s'avesse a pagare anche qualche laico sonatore. Quanto al conte Simunich, dilettante di violino, a di musica galante, io lo credo tanto lungi dal tenere fra la sue carte una messa da morto, che par quanto io abbia con lui amicizzia, e di famiglia e di persona, temerci che se la pigliasse meco se io giungesi a fargli una ricerca di questo genere. In tale stato di cose, e non essendomi possibile per la contrarietà de' tempi di farle avere una pronta risposta sopra ciò ho pensato di scrivere io se stesso una messa da morto, che quando non mi si frappongano straordinarj imbarazzi, spero di compire in pochi giorni. Non essendomi nota la portata gutturale di cotesti sacri cantori, penso di attenermi a una misura media, e di comporre l'armonia a due tenori e un basso che sono le voci più ordinarie. Perciò che riguarda l'orchestra, sò che costà oltre gli strumenti d'arco non mancano quei da fiato, i quali io penso di far'entrare nella mia composizione, in modo però che possa eseguirsi anche coi soli violini. La fattura è già incominciata, e forse il vento contrario, che secondo tutte le apparenze vuol durare ancora, farà ch'io la finisca prima di averle potuto mandare altra risposta. Ma intanto io apparecchio questo foglio che spedirò colla la prima occasione, perché Ella veda se mai Le poteste comodare, in mancanza di altre messe da morto, di servirsi della mia; la quale se per l'ostinazione de' tempi non arrivasse costà entro a questo mese, certamente non dovrebbe mancare di arrivarvi nel principio del prossimo venturo;il che forse ancora potrebbe convenire alle giuste e degne 


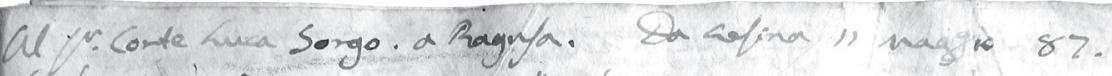

a Jua Jottera dei $p_{4} 4$ aprile proff paff. me pervenuela solam the jorni fa ex"

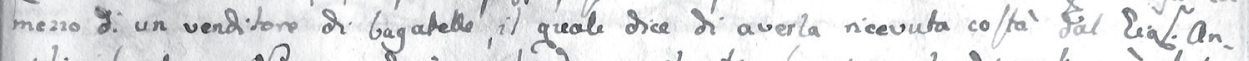

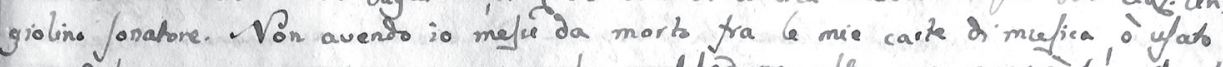
- gni Xigena per trovarne gei prefo gualchedueno altro ma non nes trovato che

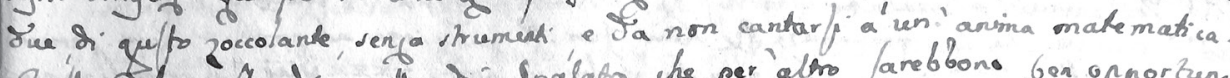

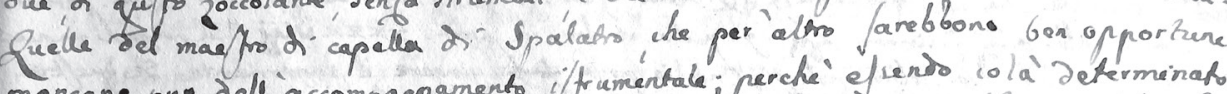
mancane pur dell accompagnamento iffumentale; perche ef uento cola' determinato

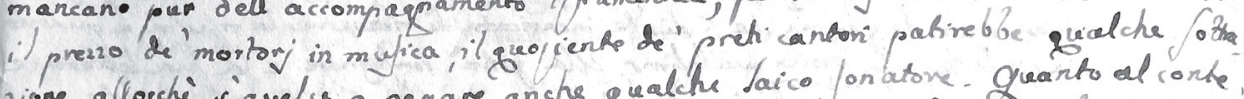

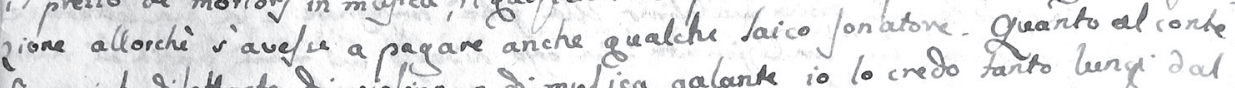

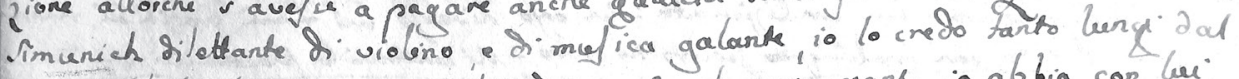
venere fra la Jue carke una malsa da morto che per geanto io ab bia cor lus" amicrizia ed famiglia ed perfora, hemens che de fa pialiass mees, de io

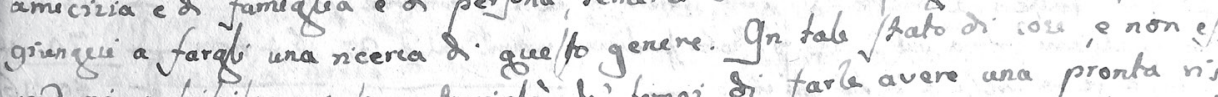

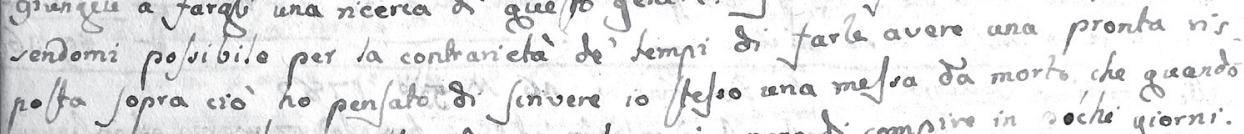

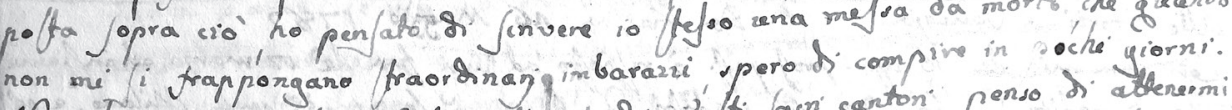

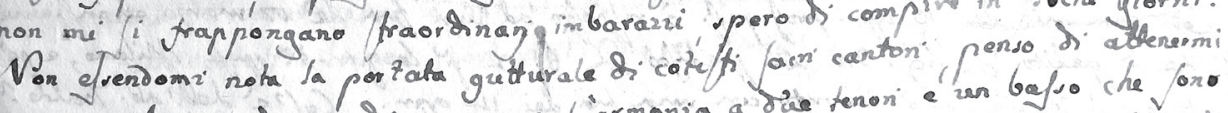

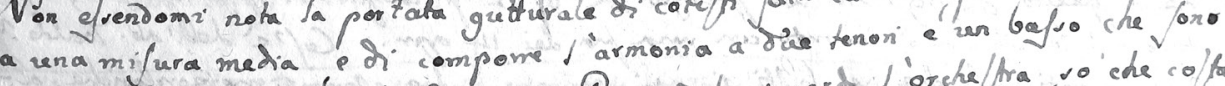

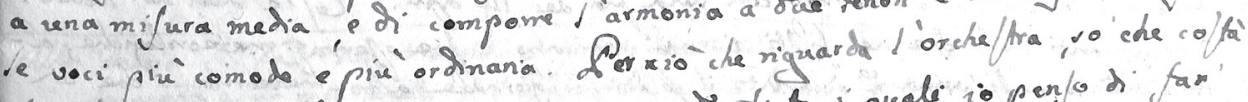

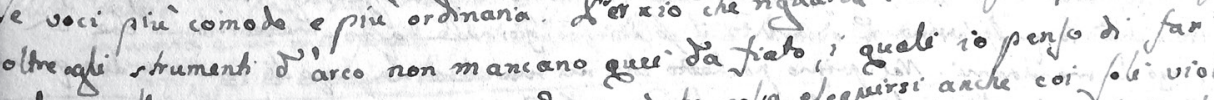

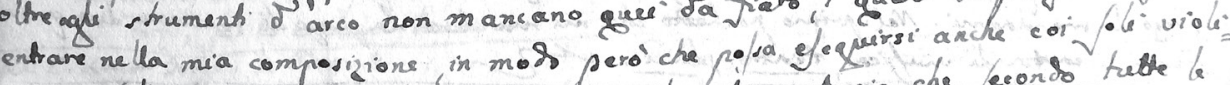

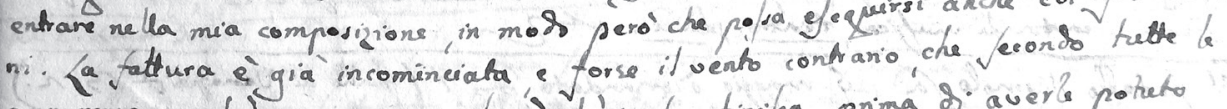
apparenge unol durane ancora tara' ch' io la finigsa prima di averls poteto

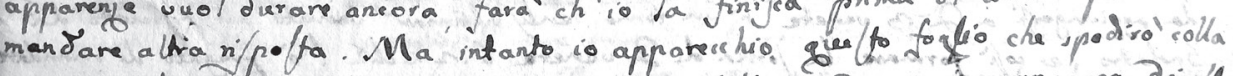
prima occatione, perche Ella veda se mai le poteff comadare, mancanza 2 , allue

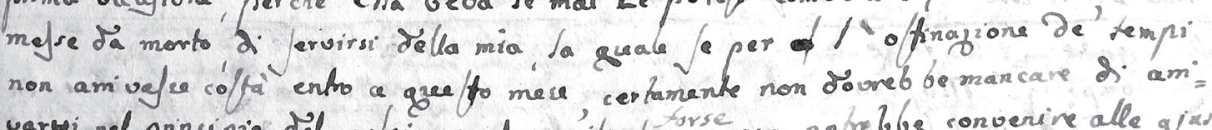

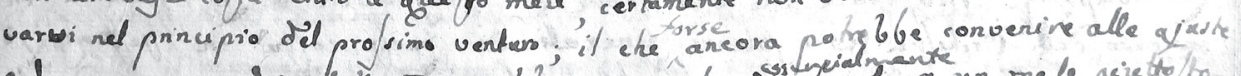

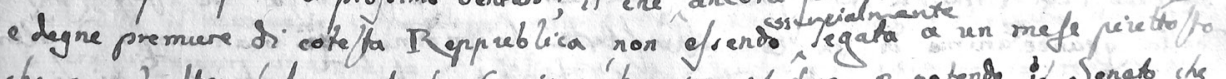

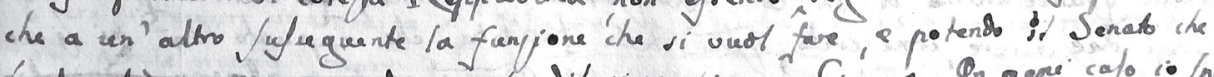

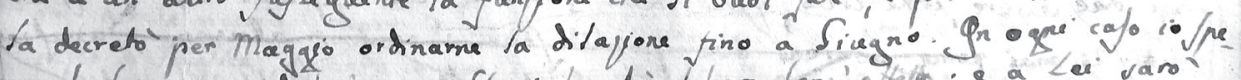

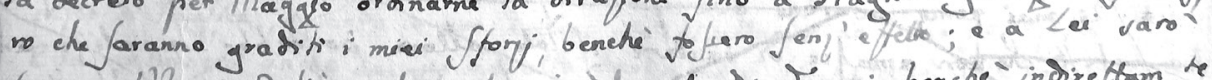

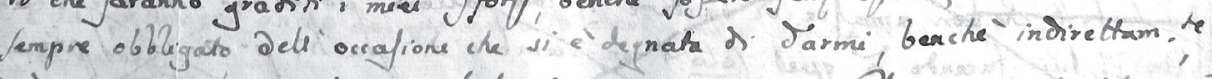

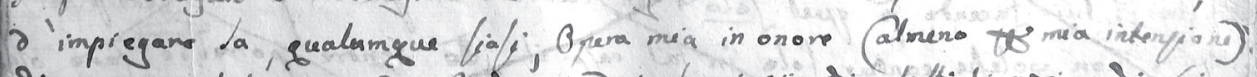

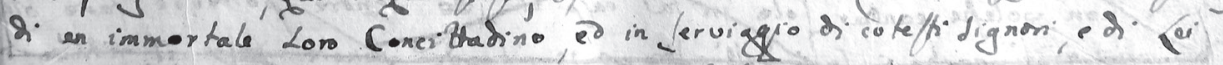

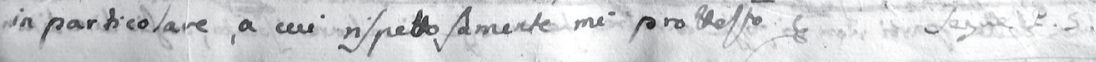

A copy of the draft of Bajamonti's letter to Luka Sorgo about his Requiem, May 11, 1787, AMS, XII/A, p. 3-4 
premure di cotesta Reppublica, non essendo essenzialmente legata a un mese piuttosto che a un altro susseguente la funzione che si vuol fare, e potendo il Senato che la decretò per Maggio ordinarne la dilazione fino a Giugno. In ogni caso io spero che saranno graditi i miei sforzi, benché fossero senzeffetto; e a Lei sarò sempre obbligato dell'occasione che si è degnata di darmi, benchè indirettam(en)te, d'impiegare la, qualunque siasi, Opera mia in onore (almeno p [er] mia intenzione) di un immortale Loro Concittadino ed in serviggio di cotesti Signori, e di Lei in particolare, a cui rispettosamente mi prottesto...

\section{Appendix 2 \\ Excerpt from Bajamonti's letter to Luka Sorgo, May 23, 1787, XII/A, AMS, p. 4-5}

Al Sig(nor) Co(nte) Luca Sorgo a Ragusa.

Da Lesina 23 Maggio 87.

La Composiz(io)ne Musicale che ho l'onore di trasmettere a Lei siccome incaricato dell'Orchestre p(er) i solenni funerali da farsi costà in suffraggio della grande anima di un loro iliustre Cittadino, in mancanza d'altri pregi dee avere, como credo, q(ue)llo della facilità che appunto da Lei si cercava. Se mai in alcuna delle parti non vi fosse cantore che amasse di restare isolato, voglio dire di cantare i solo alloro potrà forse supplire un cantore di unialtra delle parti: cosi un primo tenore o un basso oltre ai solo proprj potrebbe fare $i$ solo del tenore secondo, e questo i solo del primo o del basso: che se q(ues) to cambio non potesse aver luogo in tutti i solo potrà certam(en)te effettuarsi nella maggior parte de med(esi)mi. Perciò che riguarda glaccumpagnam(en)ti, so che costà o hanno stromenti da fiato oltre a q(ue)lli darco, e credo che non ci sarà bisogno di sostituz(io)ni: a ogni modo se mai p(er) qualche accidente mancassero gli Oboè, o i Flauti, o i Corni, e la Tromba, si potrà ne' passi obbligati supplire con due Violini, o coll'organo. Ora non manca altro che 'l tempo favorevole e una occasione o diretta, o mediata p(er) farle giungere lo spartito di q(ues)ta Messa che pron-tiss(i)mo, e che desidera di presentarsi a Lei, e col di Lei mezzo a cotesti Sig(no)ri tutti, presso a' quali la prego di conciliare al med(esi)mo quella indulgenza chesso non merita $p(e r)$ altro se non per la buona intenz(io)ne dellautore, il quale pieno di venerazione e per il sublime ed immortale Boscovich, i per tutti cotesti Signori, con particolare stima, ed altamamento si protesta... 


\section{Appendix 3 \\ Excerpt from Bajamonti's letter to Luka Sorgo, \\ May 24, 1787, XII/A, AMS, p. 5}

Al C(onte) Luca Sorgo. A Ragusa.

Da Lesina 24 Maggio 87.

Alla messa aggiungo un sonetto, non so con qual fronte! Im(m)aginandomi le belle ed eccellenti cose che si saranno fatte da cotesti squisiti poeti, io non dovea esporre niente del mio: ma la voglia di fare omaggio al gran Boscovich e alla sua patria, mi rende ardito. Io sono sicuro ch'Ella vorrà aver la bontà di mandarmi l'elogio e le altre composizioni prodotte in questa occasione, le quali cose tutte io spero di vedere colle stampe di costà...

\section{Appendix 4 \\ Excerpt from Bajamonti's letter to Luka Sorgo, July 19, 1787, XII/A, AMS, p. 14}

Al C(onte) Luc'Antonio Sorgo a Ragusa.

Da Lesina 19 Luglio 87.

Il mio Spalatrino che con buona ed onesta maniera Le si esibi di farmi tenere le di Lei lettere, se è burlato di Lei, e di me, e per colpa del medesimo io non ho ancora potuto sapere se la mia messa sia costà giunta a tempo per i funerali del Boscovich solamente dalla di Lei lettera de' 25 del prossimo passato Giugno prendo motivo di compiacermi che la detta mia fattura sia stata da Lei, e da cotesti altri Sig(no)ri accolta con bontà in un privato concerto. Con unialtra sua dei 26 detto ho ricevutto il complimento illirico-poetico della sorella del defonto allauttore del funebre elogio, e rendo le dovute grazie alla degna nutricia delle nazionali musi per la memoria che conserva di me. Ringrazio anche la Sig(nor) a Gozze di Lei nipote per il suddetto elogio mandatomi, ma non pervenutomi... 


\section{Appendix 5 \\ Excerpts from Bajamonti's letter to Miho Sorgo, \\ August 2, 1789, XII/A, AMS, p. 100, 101, 102}

(p. 100)

Al C(onte) Michele Sorgo a Ragusa

Da Les(in)a 2 agosto (1)789

Eccole di bel nuovo l'elogio del Boscovich ch'io ò creduto di migliorare. Possa il fatto corrispondere alla mia buona intenzione. Io l'aveva già scritto con uno scarso ajuto di materiali, e mera riuscito per verità troppo magro e meschino. Di cose d'altri sullo stesso argomento io non aveva veduto che l'orazione del Zamagna, e due brevi coserelle nel giornale di Vicenza. Mi mancava la maggior parte dell'opere del mio eroe non avendo io avute in mio potere che le poche datemi già dal S(igno)r di Lei fratello, e sono soltanto quelle ch'egli avea doppie fra tutte le altre da lui possedute. Non è già che io avessi voluto dare gli estratti di tutte, ma ne avrei potuto trarre varj sugosi cenni. Ora rileggendo la mia fattura ò creduto bene di esporre più chiaramente

(p. 101)

teoria boscovichiana dell'unica legge delle forze naturali: e a far ciò mi sono servito dell'opera sopra tale argomento, la quale ò presso di me. Ò aggiunto anche un cenno sopra le operette antiquarie del Boscovich. Sulla fede poi dal Ricca ò aggiunto la notizia di alcune cose che si leggono nelle illustrazioni boscovichiane sopra il poema dello Stay; e dell'aver il Boscovich nel suo viaggio astronomico per lo stato pontifizio scoperte alcune macchie di alcuni famosi matematici. Dal Ricca ${ }^{21}$ ò anche preso l'anedoto che il Boscovich fu creduto un mago dagli alpigiani in occasione del detto suo viaggio astronomico, e varie paricolarità che riguardano il nostro eroe da quando fu professore a Pavia fino al suo stabilimento in Francia, e dalla partenza sua da quel regno fino alla sua ultima malattia. Quanto alle cose dell'altra vita, non l'o levate interamente, ma mi par di averle moderate e poste in un aspetto meno urtante; poichè dove prima io aveva scritto assolutamente che l'anima di Boscovich passeggia di cielo in cielo, che va nel purgatorio di una stella o di un sole, ed altre si fatte impertinenze, ora comincio dallo scrivere che se ci fosse lecito di vedere nellaltro mondo forse potremmo dire varie belle e nuove cose, e in seguito dicendone io (non so se di belle o di brutte) sempre ci metto un forse un chi sa; e finalmente

${ }^{21}$ References to Francesco Ricca's Elogio storico dell' abate Ruggiero Giuseppe Boscovich (Milano: Nella stamperia di Giuseppe Marelli con licenza de’ superiori, 1789). 
quando sono al punto del purgatorio mi ravvedo e confesso di aver vaneggiato. Oltracciò per salvare qualche riguardo inquisitorio ò posto a piè della pagina ps., una nota o prottesta da buon cristiano facendo apparire buoni cristiani anche gli editori dellelogio. Che se ad onta di tutto ciò Ella trovasse ancora della stravaganza nelle mie fantasie, io ardirei di dire che un po' di stravaganza fa bene e si fa leggere più volentieri. Io scommetterei che la maggior parte di quelli che leggeranno (se ciò avverrà mai che vábbiano leggitori di sì fatta cosaccia) il mio elogio del Boscovich, proveranno minor noja quando saranno arrivati a forza di pazienza al viaggio della di Lui anima d'uno in un altro cielo, e di pianeta in pianeta e di cometa in cometa, di quello chè nell'altre più serie e più esatte parti dello scritto. Poichè abbiamo a quest'ora parecchi elogi di questo grande uomo, come s'avrebbe a distinguer il mio dagl'altri se non in grazia di qualche stravaganza? Benchè, a dir vero, cè per altro ne' tratti sospetti che un poco di poesia? Ora non abbiamo noi della poesia nelle prose de' piu celebri e grandi scrittori di eloquenza, e di filosofia cominciando da Platone e terminando nel Massillon? A ogni modo io mi rimetterò al giudizio di Lei e d'altri intendenti, nè mi dorrà d'esserne corretto anche un altra volta, anzi me ne pregierò. Del resto ò in parte levate e in parte modificate certe riflessioni troppo ricercate e poco spiritose ch'io aveva estese sopra l'imbecillità in cui cadde il Boscovich prima dellultima sua malattia. E finalmente per ciò che spetta a quanto scrissi

(p. 102)

in fine dellelogio sopra la stanchezza delle matematiche e sopra la sicurezza del Boscovich di non aver mai a restare oscurato dal confronto d'illustri successori, Ella forse, notando si fatti passi, à voluto tacciarmi di esaggerazione e adulazione: maio con sua pace (se mai Ella avesse presa la cosa per questo aspetto) io scrissi a quel modo di buona fede, e con intima persuasione che cosi sia e debba essere. Che v'abbia ormai dell'intermittenza nel fervore delle matematiche, mi pare che sia cosa di fatto. Che il Boscovich non debba restare oscurato da illustri successori, io lo credo detto con tutta moderazione, perchè io non dico già che non v'abbiano ad essere anche in avvenire de'grandi matematici, ma non credo che abbiano a far divenire picciolo il Boscovich, siccomesso nè il gran Newton non fecero diventar piccioli Euclide, Archimede o altri antichi.

S'Ella farà degna d'essere stampata costà la mia fatturaccia, il che lusingherebbe molto la mia ambizione, io suppongo che ci porrà il semplicissimo titolo: Elogio del Boscovich. Quando si dice Boscovich s'intende il grande, il famoso, il distinto chè appunto Ruggiero, non già Boxo o altri. Il luogo delledizione espresso nel frontispizio annunzierà essere questo fra gli elogj boscovichiani 
addottato dalla patria del lodato: onore ben grande pel lodatore. Alcuni passi che si leggono nell'introduzione o principio dellelogio testificheranno la stima e l'omaggio dell'autore verso i compatrioti del suo eroe e saranno la più naturale e la più ingenua di tutte le dedicatorie. Ancora io suppongo si adotterà un ortografia ben intesa, oggidi usata da più ragionevoli scrittori e stampatori, senza iniziali majuscole, fuorchè ne' nomi proprj e in principio di periodo, $e$ senza molte virgole. Finalmente la forma non molto grande delledizione donerà alla stessa uneleganza di più. Ma troppo grave torto ò fatto io a chi dirigerà cotesta stampa collestendermi tanto in cosi fatte minuzie.

I nostri complimenti chez vous. A quest'ora avrà ricevuto le ottave.

\section{Appendix 6 \\ Miho Sorkočević's letter to Bajamonti, October 23, 1779, XII/B-111-3, AMS}

Am(ic)o Stim(atissim)o

Per mancanza d'occasioni non ho prima d'ora risposto all'ultima vostra lettera, doppiamente cara per l'aviso che in essa mi date dellarrivo a cod(est)a parte del nostro Fortis; Egli è desiderato da tutti i suoi Amici, in particolare da me che godo in anticipazione, pensando al piacere che averò nel riattaccare la nostra conversazione; Solo temo che poiché esso passeggia le amene vie delle Città Italiane, con torvo ciglio, non abbia a corrucciarsi seriamente all'aspetto della mia Sparta. Dico questo per ischerzo, sapendo quanto esso è Filosofo, discreto, e grazioso in particolare colli amici; Credo che sia ito a trovarne ora uno a Imoski, che trovasi Proveditore; Salutatelo dopo che sarà disceso alla Marina, $e$ diteli che ho ricuperato le sue robbe che trovansi trasportate in mia casa. Ho pure una lettera per lui. Vi prego pure di riverirmi il Sig(nor)e D(otto)r Urbani, ed avermi in grado de vostri veri Amici

Rag(us)a 23 Ottob(r)e 1779

$D$ (evotissi)mo Aff(ettuosissi)mo Ser(vitore) Am(ic)o

Michele di Sorgo 
Am: frinó

Ler mancanza d'uccasiomi non bí prima dóra risporto all' uliima cortra lettera, doppiamente cara per laviso che ix essa mi date dell' amivo a cucl." parze del noitro Fortsi. Eghi é desiderato da tuti i fnoi Anvici, in particolare da me che godo in anticipar= ione, pensando at piacere che avero nel nouraccare la nostra Converrazione; Solo temo che porichè esso passeggra le amene vie delle Citri Grahiane, con = torw cighio, non ablia a corncuciansi seriamente all' aspero deha ma parizas. Fico quasto per ischerno, sapendo quanto esso e'Filosofo, disireto, e graziaso in partiolare coll amici; Credo che sia ito a truvarne ara uno a gmosali, che trovasi Provediture; Salutatelo dopo che vara' disceso ala olavina, e diteh che hi rimperato le sue che trovarsi traspostare in mi Casas. Bo pune una Cettera per lini. Si prego pume di riverirm if fig? D. Urfam; ed averm in gracio de votn veni Amià. Rag.23 Buob: 1719

Diñ Afgimo Rev: Am:

Slicbele di Sorgo

A copy of Miho Sorkočević’s letter to Bajamonti, October 23, 1779, AMS, XII/B-111-3

-36 - 